\title{
ONE HUNDRED YEARS OF THE NETHERLANDS SOCIETY OF INTERNATIONAL LAW (1910-2010)
}

In November 2010, the Netherlands Society of International Law (Nederlandse Vereniging voor Internationaal Recht, NVIR) celebrates its centenary. The NVIR was established in 1910 as the first national branch of the International Law Association (ILA). From 15 to 20 August 2010 the Netherlands Society will host the 74th Conference of the ILA, which is to be held in The Hague. It is for the fifth time that the ILA will have assembled in the Netherlands and the fourth time that The Hague has been chosen to host the ILA members from its 45 branches all over the world. ${ }^{1}$ The theme of the 74th Conference 'De Iure Humanitatis, Peace, Justice and International Law' very well reflects the present nature and essence of international law and its development from interstate law into law for humanity.

The 74th Conference in The Hague together with the centennial anniversary of the Netherlands Society are important events to celebrate. During the hundred years of its existence the NVIR has played a prominent role in the understanding and respect for international law in the Netherlands. New developments in international law - both public as well as private - are studied and discussed at the annual meetings of the NVIR. Since the days of Hugo Grotius (15831645) Dutch legal scholars have taken a great interest in this important area of the law. The NILR, founded in 1953, is one of the renowned international legal journals which is used as a platform for the study, clarification and development of international law by legal scholars all over the world. Between the NVIR and the NILR strong links exist; often, editors of the NILR have been, and still are, members of the NVIR board and the NILR has published English translations and summaries of important NVIR preliminary reports (preadviezen).

The Editorial Board thought it appropriate to publish a special issue commemorating the NVIR's centenary. This issue is dedicated to the development of international law in the Netherlands. Contributions have been written from a Dutch perspective. Apart from the history of the Netherlands Society, eloquently described by Arthur Eyffinger, attention is paid to the development of international law in the Netherlands. Paul Vlas pays attention to the development of private international law in the Netherlands since the establishment of the Hague Conference on Private International Law in 1893 up to the codification of private

1. The Hague hosted the 3rd Conference in 1875, the 30th in 1921 and the 54th in 1970; the 40th Conference in 1938 took place in Amsterdam.

Netherlands International Law Review, LVII: 141-142, 2010

(C) 2010 T.M.C. Asser Instituut and Contributors

doi:10.1017/S0165070X10200013 
international law in Book 10 of the Dutch Civil Code. Ted de Boer gives some thoughts on the separate development of public and private international law, and the differences and similarities. In the contribution by Joseph Fleuren the application of public international law by the Dutch courts is described, whereas Nico Schrijver focuses on important Dutch initiatives and landmark events in the development of international law. Thomas Henquet pays attention to problems of jurisdictional immunity with respect to the international organizations hosted by the Netherlands. The position of the Netherlands in the development of international criminal law is the subject of the contribution by Larissa van den Herik. Finally, Ellen Hey reflects on the Dutch contributions to the development of international environmental law.

The Board is extremely grateful to all contributors to this special issue, which gives a fine image of the Dutch engagement with international law in its broadest sense. The Board congratulates the NVIR on its centennial anniversary. May the NVIR flourish in the next hundred years and contribute to the development of international law in the Netherlands!

The Board of Editors 